\title{
农业水利工程灌溉中节水措施的应用
}

洪鹏

新疆生产建设兵团第一师塔里木灌区水利管理处

DOI:10.32629/hwr.v3i5.2167

[摘 要] 农业水利灌溉工程具有复杂性、系统性特点,设计较多专业知识且与农业发展有着密切联系。传统灌溉工程水资源 消耗量大, 不利于节水、节能。为此, 提出水利工程灌溉应用节水措施, 提升工程价值与运行水平, 单位给予高度重视、加大监督 管理从而达到环保效果, 实现管理效益。接下来, 笔者结合实践研究, 农业水利工程灌溉中节水措施的应用方法进行简要分析。 [关键词] 农业水利工程; 灌溉; 节水措施; 应用方法

我国水资源利用率大, 水资源紧张, 不利于农业发展, 尤 其是水利灌溉。现阶段, 农业科技水平、资金补给不足, 减少 水资源应用率。结合农业发展现状, 明确节约水资源目标, 将节水措施运用到农业水利灌溉, 加大水利工程监督管理应 将环保经济运营管理为核心, 落实节水灌溉技术应用制度, 积极转变管理形式, 提升水利工程综合效果。

\section{1 农业水利工程灌溉节水措施技术种类}

农业发展中想要提高管理效果, 综合农作物产量与产值 管理制度, 通过合理灌溉减少运输与应用浪费, 健全农业工 业可持续发展流程。加强节水综合水平并提高水资源使用 率。当前常见水利工程节水灌溉技术有: 第一, 渠道防渗, 该技术应用较多, 为人工作业提供便捷, 增强管理水平。第二, 滴管式技术。该技术有高精密性特征, 该技术可以确保植物 种植管理效果, 满足农作物生产要求, 降低产量、避免水资源 浪费。第三, 稳雨水集蓄技术。该项技术存在较多限制, 主要 适合应用干旱、半干旱趋于, 防止水土流失。不过, 该技术成 本投入大, 输水管道漏水不利于水资源节约。

\section{2 农业水利工程灌溉节水技术的重要性}

在水资源越来越缺乏、越来越宝贵的今天, 如何科学用 水、合理灌溉, 更好地采用节水新技术、新设备是农业水利 灌溉的重要课题, 而健全完善节水农业技术体系, 则能够充分 利用农用水资源, 全面提高灌溉水的利用率和利用效率。因此, 节水农业技术体系、节水管理技术体系是一种能够使农作物 达到高产、高效所采取的技术措施。如果科学合理的运用由 水资源、工程、农业、管理等环节的各种节水技术组成的综 合技术体系, 不但能够迅速提高农用水资源的整体利用率, 还能够大幅增加单位面积和总体面积农作物的产量, 提升综 合效益, 全面促进农业经济的持续和稳定发展。

水资源作为农业发展重要组成部分, 是推动农业发大战 的关键性因素。以往农业灌溉多为大水漫灌, 造成水资源浪 费, 与我国可持续发展理念背道而驰。为此, 提出节水措施, 第一, 减少水资源使用率。水利灌溉时, 节水措施主要优势为 节约水资源。因为农业灌溉所用水量较大, 实施节水措施后 能够节省很多无效用水, 提高水资源利用率, 改善农业生产 需求、解决供给不足方面发挥重要作用。第二, 促进生产效
率进步。农业水利灌溉根据农作物生长状态确定用水量, 利 用先进设备在保证节约用水的同时保证充足水量, 自然环境 和有关因子融合, 从而扩大农作物产量与质量, 实现产量提 高。第三, 节约劳动力。水利灌溉应用先进技术可以取缔较 多人力资源, 缩小作业面积, 真正做到了让农户脱离农田, 实 现智能化、自动化操作, 优化劳动力结构, 促进农村产业发展。

\section{3 农业水利灌溉节水技术的应用方法}

3.1 农业节水技术体系与管理体系

水资源的合理利用要求科学应用工程措施, 比如: 机井 测试改造技术、多水源应用技术。灌溉节水技术体系也是主 要内容, 分为低压管道灌溉、喷灌技术等。农业节水技术体 系分为包括蓄水保墑耕作技术、适雨种植提高作物抗旱能力 的栽培技术、秸秆覆盖或地膜覆盖保墒技术、化学药剂抗早 保墒与保水剂应用技术、限额灌溉及节水抗早作物品种选育 技术等。节水管理技术体系就是要建立健全各种管水组织, 制定工程管理和经营管理制度, 作到计划用水、优化配水、 合理征收水费。

\section{2 制定节水完整体系}

现阶段, 农业节水措施无法从根本上解决水资源紧张问 题, 为扩大农作物产量, 农户们开始打更深的井、井的数量也 越来越多。而应用节水灌溉节约的水资源不断扩大灌溉面积, 并非根本上资源节约。笔者认为: 我们要从可持续战略发展 角度分析节约措施, 节水不仅是农业水利工程研究内容也是 技术问题, 更是权社会需要面临的问题, 存在很多农业种植 结构调整、家庭联产承包承包责任制、农民利益等多方面问 题。为此, 我们有必要的联合多个部门、统筹协调、可结合 农业节水发展影响要素, 因地制宜的制定系统的节水农业技 术体系。

3.3 科学规划, 节水有效推进

灌区地面水应用分为内栏蓄和区外引水系统, 分析获得 多年可供水资源过程。灌区地下潜水层的作为调节水库, 补 给量分为降雨补给, 渠道、排水渗漏补给, 区外地下水侧向补 给, 区内地下水越层补给和人工回灌等。消耗量分为: 蒸发、 开采、出流。多种水源统筹协调, 确定地表水对地下水的补 给量、补给区域。结合补给形式与开采强度的确定区域开采 
布局。冲积平原或河流的中下游, 地下水位较高, 外引水源可 靠性较低时, 发展井灌, 用井补渠。如果地下水开采过度需减 少用水, 修建蓄水工程, 通过河流水源引水存蓄或回灌地下 水。如果处于相同灌区, 地面水、地下水动态规律不易, 以渠 为主, 下游井渠融合, 以井为主。

3.4 加强扶持, 明确节水的作用

现如今, 农业节水工程投资途径有集体出资、农民筹资、 国家补助。项目经济投入较高, 补助资金少, 多数资金要由农 民筹借, 没有更多资金投入到节水工程中。因此, 政府应将农 业节水列入重要工作内容, 创建制度, 在政策、资金等方面加 大扶持, 明确农业节水的重要作用, 树立良好的社会风气。

\section{5 低产田要效益, 扩大灌溉面积}

选择适合的节水灌溉技术, 根据田间环境制定发展目 标。中低产田成为今后农业发展主方向, 由中低产田增强效 益, 扩大节水灌溉面积。盐碱做好以水冲盐、以水压碱与土 壤改良, 制定适合的冲洗定额与节水技术方案。

\section{4 农业水利节水灌溉技术发展形势}

科学技术技术的进步, 今后我国农业水利节水灌溉技术 发展趋势集中于以下几点: 首先, 喷灌技术、滴灌技术, 根据 农业水利灌溉要求与发展方向综合应用。根据灌溉技术特征 因地制宜的应用, 多灌溉技术融合实现灌溉效益最大化。其 次, 地下灌溉技术的推广作为高效技术, 但实际落实效果较 差, 存在诸多技术不足,一些关键技术有待提升, 今后发展空 间巨大。最后, 灌溉技术逐步走向成熟, 节水灌溉管理成为重 要内容, 成为高效节水的影响要素, 要求共组人员加大对节 水灌溉的管理, 创建资源数据库与模型, 实现质量、空间的精 准灌溉。

政府相继颁布了《全国农业可持续发展规划(2015-2030)》、 《水污染防治行动计划》等有利于节水灌溉行业的产业政策, 从水利、农业、农业综合开发、土地整理以及城市园林等行 业和领域入手加大对节水灌溉工程的投入。2015年5月农业 部印发的《全国农业可持续发展规划 (2015-2030)》中提出,
“到2020年发展高效节水灌溉面积2.88亿亩; 到2020年和 2030年全国农业灌溉用水量分别保持在 3,720 亿立方米和 3,730 亿立方米; 确立用水效率控制红线, 到 2020 年和 2030 年农田灌溉水有效利用系数分别达到 0.55 和 0.60 以上。” 根 据上述政策, 自2016年至2020年, 我国每年喷滴灌耕地面积 需新增 3,000 万亩, 喷滴灌设备市场容量约为 300-400亿元。 农业节水政策的实施和推广必然使得我国的节水灌溉行业 未来发展潜力巨大, 节水灌溉行业面临新的发展机遇, 政策 红利释放为行业发展的大好前景提供了有力保障。

\section{5 结语}

总而言之, 农业水利灌溉想要实现水资源节约, 增强生 产效率必须要实施节水措施, 应用节水灌溉技术, 创建系统 的节水灌溉系统、提升灌溉利用率, 控制水资源的使用, 提高 农业灌溉效益。真正做到了让农户脱离农田, 实现智能化、 自动化操作, 优化劳动力结构, 促进农村产业发展。此外, 提 高水利工程运行水平与价值, 有关部门加大管理力度, 实现 环保与管理双赢。

\section{[参考文献]}

[1]杨青岩.农业水利工程的节水灌溉技术应用及其措 施[J].建材与装饰,2019,(10):289-290.

[2]张海涛.农业水利工程的节水灌溉技术应用及其措施 分析[J].工程技术研究,2019,(03):93-94.

[3]袁有衡.农业水利工程灌溉中的节水措施研究 [J].江 西农业,2019,(02):45.

[4]张云红.农业水利工程的节水灌溉技术应用及其措施 [J].农民致富之友,2019,(03):93.

[5]彭先云.浅析节水措施在农业水利灌溉中的应用价值 [J].南方农业,2018,12(35):148+154.

[6]乔宝花.浅析节水措施在农业水利灌溉中的应用价值 [J].农业科技与信息,2018,(23):102-103.

[7]许国安.农业水利工程的节水灌溉技术应用及其措施 [J].居舍,2018,(33):71. 